Copyright (C) 2021 by Cherkas Global University

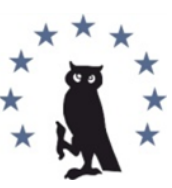

Published in the USA

European Journal of Physical Education and Sport

Has been issued since 2013 .

E-ISSN: 2409-1952

2021. 9(1): 3-12

DOI: 10.13187/ejpe.2021.1.3

https://ejpes.cherkasgu.press

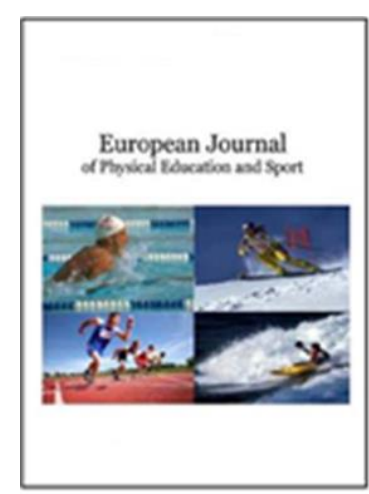

Articles

\title{
The Correlation between the Emotional-Social Interaction of a Professor of Physical Education and Sports and his Students in the Physical Education and Sports Lesson
}

\author{
Harbach Brahim a, *, Guezgouz Mohamed a, Bendehiba Djourdem a \\ a University of Abdelhamid Ibn Badis-Mostaganem, Algeria
}

\begin{abstract}
The aim of the study was to determine the correlation between the emotional-social interaction of a professor of physical education and sports and the activity of his students during the physical education and sports lesson, where the researchers used the descriptive approach, and the sample comprised $(\mathrm{N}=14$ ) teachers, and (398) students (aged $12 \pm 14$ years) from 14 Middle school of Mostaganem state, the researchers used The questionnaire form and the Weethol scale to measure the social-emotional interaction; they used the SPSS program in the statistical analysis of the data got we considered the results of statistical tests significant with $\mathrm{p}<0.05$; the results showed the existence of a positive and strong correlation between the first three behavioral groups of the tool, and the extent of student activity and the researchers recommend using indirect methods by professors in teaching, whether verbal or kinesthetic. The results of the sample showed that the arithmetic mean was $(02.30 \pm 88.30)$, and the standard deviation ranges within limits of $(01.10 \pm 20.40)$, the calculated value of $(\mathrm{R})$ was $(-0.97 \pm 0.94)$, It is greater than the table $(\mathrm{R}=0.55, \mathrm{df}=13, \mathrm{p}<0.05)$ and it is at the level of significance. We conclude that there is a significant correlation between the first three behavioral categories of Weethol's tool and the extent of students' activation and that there is an inverse relationship between the last three categories of behavior and the extent of students' activation.

Keywords: social emotional interaction, professor of physical education and sports, student activity, the physical education and sports lesson.

\section{Introduction}

The teaching process consists of a group of important components or elements, namely the teacher and the student, the educational objectives, the skill or the content of the lesson, the tools and equipment used, the methods, methods and teaching strategies, the professor's interactions and social interactions with the pupils, the procedures and steps followed in organizing the lesson, classroom management, evaluation and all of these The components need a teacher with a sufficient degree of experience to deal with them and in a way that achieves the desired goals. (Hayek, Sadiq Khaled, 2018: 57).
\end{abstract}

\footnotetext{
* Corresponding author

E-mail addresses: brahim.harbach@univ-mosta.dz (B. Harbach)
} 
The component of the professor's socio-emotional interactions with students is among the most important components of the teaching process, and it is the critical element that if the teacher mastered it, he helped him achieve The greatest amount of motivation for pupils and their revitalization of the teaching process and the participation of pupils in the output of the lesson.

Through the above, we wanted from our research this link between pupils' activity during their exercise of the lesson of physical education and sports and the social emotional interaction of the professor who is distinguished by means of adaptation, cooperation, communication, communication, etc. (Othman, 2013; Ahmed et al., 2010; Abdel hadi, 2004; Doraj, 2012).

The physical education and sports lesson is considered one of the forms of academic subjects, such as natural sciences, physics, and literature, as they meet in methods and objectives, and their curricula and content differ, but they fall into one point, which is to provide students with knowledge and direct them to a healthy future. The presentation of the physical education and sports lesson differs from these subjects in He does not care about the cognitive and scientific fields, but goes beyond that to the physical, psychological, social and health fields through activities (Harbach et al.,. 2020). In this regard, Muhammad Abu Odeh says, "Physical education and sports do not aim to form the individual from the physical point of view only, but rather its purpose is higher than that, it is the formation of the individual. Balanced in all its physical, moral, mental, social and psychological aspects, in addition to what the individual acquires in terms of healthrelated information in terms of hygiene and healthy behavior, as the general information of the individual increases through his contact and mixing with different external societies and interacting with them socially and culturally (Abu Odeh, 2009), which confirms that physical education And sports are not less important than the rest of the subjects, given their necessity in developing important aspects of the student's personality, especially from the social aspect. Which brings the student to adaptation and integration within the class, meaning the strengthening of relationships between students and the decoupling of isolation from each other, thus promoting proper adaptation?

The success of the physical education and sports lesson is limited to the role of the professor in presenting the various aspects of physical and sports activities, but he has a greater role than that, as he works to provide educational duties through physical activities that aim to develop and shape the values and high morals of students, taking into account the tendencies and desires of students (Khatibeyah, 1992) where both Ahmed El-Amin and Gargour indicate that there is a correlational relationship in a positive direction between each feature of the teacher's calmness and the motivation of perseverance among students and the existence of a correlational relationship in a positive direction between the social characteristic of the professor and the motivation of achievement behavior among students (Wadah, 2014) and Mukhtari and Yusef concluded that: "Social relations have a great impact on learning among adolescents in the study of physical education and sports and relying on group formation helps a lot in science and raising the level of students" (Mokhtari, 2018) in contrast to the study of Boughalia and Ahmad, so we find that there is a weak correlation between the competencies of a professor of physical education and sports and the dimensions of the following trend scale: social experience, health experience, stress reduction and athletic excellence (Boughalia, 2020).

Therefore, we were challenged by a problem: Does the emotional social interaction of a professor of physical education and sports have a role in motivating and stimulating students to practice physical and sports activities?

\section{Methods}

Research methodology: The researchers used the descriptive method to study the correlation between the emotional interaction of a professor and the activity of the students.

Research and Sample: The study population consisted of teachers and students of Mostaganem state schools.

The study sample comprises 398 students aged (12-14 years), fourth Middle year level, and 14 physical education and sports teachers for the 2019-2020 academic year, was randomly selected from the community of origin in the order of the table below: 
Table 1. The distribution of the research sample (teachers and students) by some middle schools

\begin{tabular}{|c|c|c|c|}
\hline Municipal & Name of the educational institution & Professor's name & $\begin{array}{l}\text { Number of } \\
\text { pupils }\end{array}$ \\
\hline Sidi Cheikh & $\begin{array}{l}\text { Zidouri Abdel kader Intermediate } \\
\text { School }\end{array}$ & Khalil & 30 \\
\hline Arboit & $\begin{array}{l}\text { Karkab abdelmalek intermediate } \\
\text { school }\end{array}$ & Benyoucef & 29 \\
\hline Bouktab & $\begin{array}{l}\text { Shirfawi Mohamed Intermediate } \\
\text { School }\end{array}$ & Mbrek & 28 \\
\hline Echkik & Madani mamar intermediate school & Fechfouch & 29 \\
\hline Elkaf & Belakid mohamed intermediate school & Djeffel houari & 27 \\
\hline Elghasoul & Abdali mohamed intermediate school & Boucek elhadj & 31 \\
\hline Echalala & Hamitou elbachir intermediate school & Slimani & 27 \\
\hline Elkhaither & $\begin{array}{l}\text { Eldjadida elkhaither intermediate } \\
\text { school }\end{array}$ & Farji & 25 \\
\hline Tesmouline & Mahari kouider intermediate school & Talbi tahar & 30 \\
\hline El Bayadh & Tajdin abdelkader intermediate school & Zair mourad & 29 \\
\hline Sidi amer & $\begin{array}{l}\text { Lkhadari mohamed intermediate } \\
\text { school }\end{array}$ & Laribi amer & 26 \\
\hline Bousamgho & Tarek ben ziad intermediate school & Rajaa salem & 31 \\
\hline Ain elirak & $\begin{array}{l}\text { Youcefi mohamed elwassini } \\
\text { intermediate school }\end{array}$ & Bachiri & 27 \\
\hline Brizina & Boukhabza elbay intermediate school & Koiadri salem & 29 \\
\hline \multicolumn{2}{|c|}{ total summation } & 14 & 398 \\
\hline
\end{tabular}

\section{Materials}

- The human field: represented by teachers and students of some of Mostaganem state schools.

- The pilot survey from $08 / 11 / 2020$ to $18 / 11 / 2020$.

- The basic experiment was conducted from 10/12/2020 to 30/12/2020.

- Filming was done for the exploratory experience in Mostaganem state schools.

Data collection tools:

First: Foreign sources and references. session.

Second: Cameras to film the teaching sessions, then take a sequence of 30-minute of each 
- The main experience: The cinematography of the teaching sessions of physical education and sport (14 sessions) was carried out in the stadiums and the rooms of the educational establishments of the state of Mostaganem.

\section{- Preparing the form and explaining the measuring tools:}

To build the questionnaire (related to student activity), we consulted with some teachers, and phrases we are extracted on teacher motivation for students, then conducting an exploratory study to survey and knowing the extent of the validity of the form (the student form) and judging it by the teachers so we used in analyzing the results and unpacking them the five-point scale of the Likert which is:

- The first axis: the psychological role (includes 12 phrases)

- The second axis: an educational and social role (includes 12 phrases)

- Method of evaluating the scale scores. Drafting the scale paragraphs with a positive form and they base the evaluation of the answer on a five-year scale. Graduation (practiced to a very large degree, we give it " 5 " degrees, it are practiced to a large extent " 4 ", it are practiced with a medium degree " 3 " it are practiced weekly "2", it are practiced very weakly we give it "1" degrees.

Through this, we have reached a review of this form and its correction by the professors. The phrases for the subject of our study (for the form and the tool) we are extracted. And after viewing it a group of experts in pedagogy the final version of the form intended for middle school students has been reached.

\section{Weethol tool to measure social-emotional interaction.}

How to observe and record with the Weethol tool in observing the social-emotional interaction of the professor:

The Weethol tool is used to observe the professor in places of study during his teaching of any systematic topic. Where the Weethol tool for observing the social-emotional interaction of the class members comprises seven behavioral categories: the first three are reinforcing for the pupils and their behavior (reinforcing behavior for the pupils, the behavior of accepting and clarifying what the students show, the behavior that helps the students to solve) and the fourth is impartial (Impartial behavior), and the last three are reinforcing For the teacher and for the behavior and roles he performs in classroom education (behavior directed at students, the behavior of rebuke, reprimand, reprimand and condemnation, the behavior of strengthening the teacher for himself) and when observing the teaching with a tool, the observer intends to sit in an area of the classroom that enables him to see what is happening in the place of study and hear what the professor is showing And students of phrases, comments, inquiries, directions, instructions, and questions. The best classroom site that enables him to do all this, seeing and hearing the course of the class without interfering or negatively affecting it, is one of the back corners of the class. The observer takes a Weethol model with him to record what happens from the seven teachers' behavior. It is preferable for the observer to attend the class at the beginning of the class, where he spends the first minutes in identifying the general components of the class and the method of organizing them, and also distinguishes the occasion or the behavioral beginning that the teacher or students initiate in the first session and usually directs the nature of events, methods of interaction and its content in the following minutes or during the whole session Sometimes the observer can, in order to facilitate the recording and the multiplicity of types of behavior, divide the session into periods of ten or fifteen minutes each, where he places a sign, Next to the type of behavior that he notices each time it occurs. The observer uses the following procedural principles to observe and distinguish the seven behavioral types that are embodied in the present Weethol tool: We summarize them in the classification of any statement, comment, question, or reference that focuses on the teacher or the student and aims in the appropriate field for it (Hamdan, 1999: 100).

\section{Research variables:} education.

- The independent variable: the social emotional interaction of teachers of physical

- Dependent variable: the extent of pupils' activity.

How to work in the basic study (procedures):

After the exploratory study, we started our basic study where one researcher tends to the intermediate level and then takes a suitable place to register with a tool for emotional-social interaction, as we mentioned above, then after the class, we distribute the form to 30 students for 
each pupil's share of direct registration classes and give a chance of (10 to 12mn) at most. To retrieve the form, the researcher answering students 'questions for some vague phrases (the form directed to them). Then we calculate the average total of (10mn) classes for each of the phrases of the Weethol tool and the average of the total of the students 'answers to the questionnaire, then calculate the correlational relationship between the emotional-social interaction and the extent to which the teacher motivated students to perform the physical education and sports class well.

\section{The exploratory study}

The exploratory experiment was conducted by the method of conducting the test and returning it in two phases, where the time difference was a week, so the researchers reached the following results: The validity coefficient ranged by using Pearson's coefficient of the questionnaire directed to the pupils of the two axes, the lowest correlation coefficient was 0,882 and the highest value 0,938 and this shows That the tool (the questionnaire directed to students) is characterized by high validity and reliability coefficient

The researchers used the stability factor, and its value ranged respectively: 0.939 and 0.968), which shows that the tool is characterized by high stability. As for objectivity, the two tools, after being presented to the aforementioned arbitrators, agreed that the tool actually used measures what it should measure, as the following table shows the validity and reliability of the students 'questionnaire: where the exploratory sample was represented by students of some averages from the white state of (07) students without the study sample The original and very similar to the original sample to ensure the validity of the measuring instrument.

Table 2. The results of the Pearson correlation coefficient to calculate the validity and reliability of the measuring instrument

\begin{tabular}{|c|c|c|c|}
\hline $\begin{array}{l}\text { Behaviors (talk of learning } \\
\text { and pupils) }\end{array}$ & $\begin{array}{l}\text { Sample } \\
\text { volume }\end{array}$ & $\begin{array}{l}\text { Computed } \\
\text { correlation } \\
\text { coefficient }\end{array}$ & Honesty Lab \\
\hline The first axis & \multirow[t]{2}{*}{07} & 0,82 & 0,90 \\
\hline The second axis & & 0,98 & 0,99 \\
\hline
\end{tabular}

Through Table 2 it is evident that the validity coefficient of the axes that make up the measuring tool (the students 'questionnaire) reached the lowest correlation coefficient $(0,82)$ and the highest value $(0,98)$. This shows that the tool is characterized by a high degree of honesty, and the researchers used the reliability coefficient. Self, where its lowest value ranged from $(0,90)$ and its highest value $(0,99)$. This indicates that the tool is characterized by a high degree of honesty and stability.

Statistical Analysis:

- Arithmetic means and standard deviations;

- Percentages;

- Pearson correlation coefficient;

- Reliability factor square root of the truth factor.

\section{Results and discussion}

The link between the emotional interaction of the teachers and his encouragement for the students. 
Table 3. The arithmetic averages, standard deviations and percentages of the results of unloading the tool of weethol (emotional interaction) and the form of teacher encouragement for students and the correlation between them.

\begin{tabular}{|c|c|c|c|c|c|c|c|c|c|}
\hline $\begin{array}{l}\text { Relatio } \\
\text { nship } \\
\text { type }\end{array}$ & $\begin{array}{l}\text { Statistical } \\
\text { significanc } \\
\text { e }\end{array}$ & $\begin{array}{l}\text { The } \\
\text { compute } \\
\text { d value } \\
\text { (t) }\end{array}$ & $\begin{array}{l}\text { Standard } \\
\text { deviation }\end{array}$ & $\begin{array}{l}\text { SM } \\
\mathrm{A}\end{array}$ & $\begin{array}{l}\text { The axes of } \\
\text { the student } \\
\text { motivation } \\
\text { form }\end{array}$ & $\begin{array}{l}\text { Percentage } \\
\mathrm{S}\end{array}$ & $\begin{array}{l}\text { Standard } \\
\text { deviation }\end{array}$ & $\begin{array}{l}\text { SM } \\
\mathrm{A}\end{array}$ & $\begin{array}{l}\text { Thule's } \\
\text { phrases of } \\
\text { behavior }\end{array}$ \\
\hline positive & Function & 0,94 & 4,62 & $\begin{array}{l}48, \\
59\end{array}$ & $\begin{array}{l}\text { The first } \\
\text { axis }\end{array}$ & \multirow[t]{2}{*}{$18,3 \%$} & \multirow[t]{2}{*}{11,5} & \multirow[t]{2}{*}{54,4} & \multirow{2}{*}{$\begin{array}{l}\text { Reinforced } \\
\text { behavior of } \\
\text { pupils }\end{array}$} \\
\hline positive & Function & 0,92 & 4,99 & $\begin{array}{l}48, \\
20\end{array}$ & $\begin{array}{l}\text { The second } \\
\text { axis }\end{array}$ & & & & \\
\hline positive & Function & 0,98 & 4,62 & $\begin{array}{l}48, \\
59\end{array}$ & $\begin{array}{l}\text { The first } \\
\text { axis }\end{array}$ & \multirow[t]{2}{*}{$29,7 \%$} & \multirow[t]{2}{*}{20,4} & \multirow[t]{2}{*}{$\begin{array}{l}88, \\
3\end{array}$} & \multirow{2}{*}{$\begin{array}{l}\text { Acceptance } \\
\text { behavior and } \\
\text { clarification }\end{array}$} \\
\hline positive & Function & 0,97 & 4,99 & $\begin{array}{l}48, \\
20\end{array}$ & $\begin{array}{l}\text { The second } \\
\text { axis }\end{array}$ & & & & \\
\hline positive & Function & 0,96 & 4,62 & $\begin{array}{l}48, \\
59\end{array}$ & $\begin{array}{l}\text { The first } \\
\text { axis }\end{array}$ & \multirow[t]{2}{*}{$18,7 \%$} & \multirow[t]{2}{*}{11,5} & \multirow[t]{2}{*}{55,6} & \multirow{2}{*}{$\begin{array}{l}\text { Assistant to } \\
\text { solve } \\
\text { problems }\end{array}$} \\
\hline positive & Function & 0,98 & 4,99 & $\begin{array}{l}48, \\
20\end{array}$ & $\begin{array}{l}\text { The second } \\
\text { axis }\end{array}$ & & & & \\
\hline positive & $\begin{array}{l}\text { Not } \\
\text { function }\end{array}$ & 0,05 & 4,62 & $\begin{array}{l}48, \\
59\end{array}$ & $\begin{array}{l}\text { The first } \\
\text { axis }\end{array}$ & \multirow[t]{2}{*}{$1,7 \%$} & \multirow[t]{2}{*}{1,1} & \multirow[t]{2}{*}{5,0} & \multirow[t]{2}{*}{$\begin{array}{l}\text { Impartial } \\
\text { behavior }\end{array}$} \\
\hline positive & $\begin{array}{l}\text { Not } \\
\text { function }\end{array}$ & 0,11 & 4,99 & $\begin{array}{l}48, \\
20\end{array}$ & $\begin{array}{l}\text { The second } \\
\text { axis }\end{array}$ & & & & \\
\hline positive & $\begin{array}{l}\text { Not } \\
\text { function }\end{array}$ & 0,24 & 4,62 & $\begin{array}{l}48, \\
59\end{array}$ & $\begin{array}{l}\text { The first } \\
\text { axis }\end{array}$ & \multirow[t]{2}{*}{$24,5 \%$} & \multirow[t]{2}{*}{7,5} & \multirow[t]{2}{*}{72,7} & \multirow{2}{*}{$\begin{array}{l}\text { Pupil- } \\
\text { directed } \\
\text { behavior }\end{array}$} \\
\hline positive & $\begin{array}{l}\text { Not } \\
\text { function }\end{array}$ & 0,34 & 4,99 & $\begin{array}{l}48, \\
20\end{array}$ & $\begin{array}{l}\text { The second } \\
\text { axis }\end{array}$ & & & & \\
\hline $\begin{array}{l}\text { Negativ } \\
\mathrm{e}\end{array}$ & $\begin{array}{l}\text { Not } \\
\text { function }\end{array}$ & $-0,59$ & 4,62 & $\begin{array}{l}48, \\
59\end{array}$ & $\begin{array}{l}\text { The first } \\
\text { axis }\end{array}$ & \multirow[t]{2}{*}{$0,8 \%$} & \multirow[t]{2}{*}{1,2} & \multirow[t]{2}{*}{2,3} & \multirow{2}{*}{$\begin{array}{l}\text { Behavior, } \\
\text { reprimand } \\
\text { and } \\
\text { forgiveness }\end{array}$} \\
\hline $\begin{array}{l}\text { Negativ } \\
\mathrm{e}\end{array}$ & $\begin{array}{l}\text { Not } \\
\text { function }\end{array}$ & $-0,62$ & 4,99 & $\begin{array}{l}48, \\
20\end{array}$ & $\begin{array}{l}\text { The second } \\
\text { axis }\end{array}$ & & & & \\
\hline $\begin{array}{l}\text { Negativ } \\
\mathrm{e}\end{array}$ & $\begin{array}{l}\text { Not } \\
\text { function }\end{array}$ & $-0,97$ & 4,62 & $\begin{array}{l}48, \\
59\end{array}$ & $\begin{array}{l}\text { The second } \\
\text { axis }\end{array}$ & \multirow[t]{2}{*}{$6,3 \%$} & \multirow[t]{2}{*}{6,3} & \multirow[t]{2}{*}{18,9} & \multirow{2}{*}{$\begin{array}{l}\text { Self- } \\
\text { reinforcing } \\
\text { behavior of } \\
\text { the professor }\end{array}$} \\
\hline $\begin{array}{l}\text { Negativ } \\
\mathrm{e}\end{array}$ & $\begin{array}{l}\text { Not } \\
\text { function }\end{array}$ & $-0,97$ & 4,99 & $\begin{array}{l}48, \\
20\end{array}$ & $\begin{array}{l}\text { The third } \\
\text { axis }\end{array}$ & & & & \\
\hline
\end{tabular}

Tabular value (t) at the level of significance 0,05 , degree of freedom $13=0,55$, sum of averages $=297$, and deviation $=$ 31,4

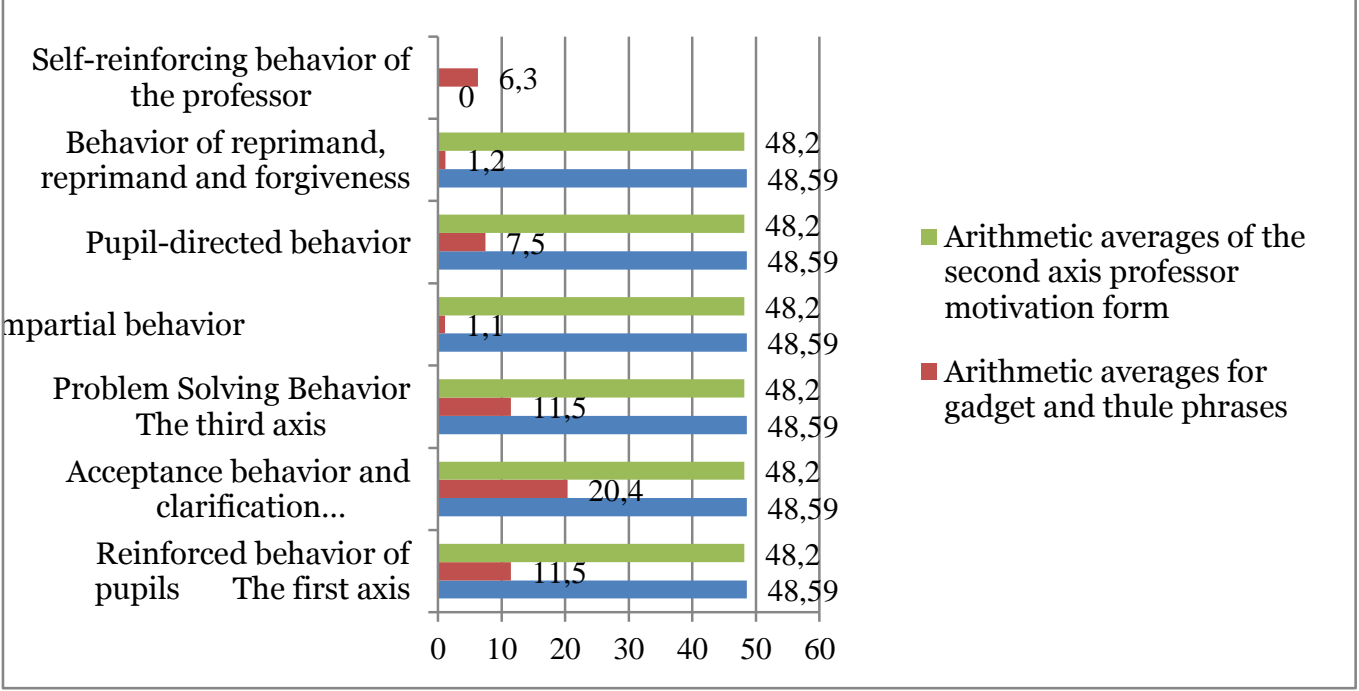

Fig. 1. The arithmetic averages for the phrases Weethol tool (the emotional interaction of the professor) and the arithmetic averages for the phrase, a comment, a question, or a reference that focuses on the professor or the student to encourage the teacher to his students.

We realize from Table 3 and Chart (01) that the calculated value of " $R$ " is greater than the tabular "R" (0.55) in the classes or types of social-emotional interactions of the indirect professor 
(reinforcing behavior of students - the behavior of acceptance and clarification - supportive behavior). On problem-solving (with two axes, the student's motivation form, which is evidence of a strong positive correlation between the type of indirect social-emotional climate that prevailed in the class atmosphere and the interaction of the teacher to encourage students and increase student activity in class. No. ( 3.2.1) the reinforcing behavior of pupils - acceptance behavior and Explanation - Helping behavior to solve problems) where the percentage of professor's behavior and interaction reached $18.3 \% 29.7 \% 18.7$ respectively in category No. 3.2.1. It can be said according to the "Weethol" tool that the professor was indirect in his interaction and building on his emotional-social interaction with the students, and thus this leads to stimulating pupils' activity during the class. As for the other groups, the calculated " $t$ " was less than the tabular but the relation in the two categories, 7.6, where the teacher's interaction and interaction rate was in the 7.6.5 category (behavior directed at pupils - rebuking and reprimanding behavior - self-reinforcing behavior of the teacher) $24.4 \%$, $0.8,6.3 \%$, respectively, so here the teacher is direct in his dealings with students and is constructive In his social-emotional interaction, and thus the return on pupils' activity is in a rapid and noticeable decline, as the percentage "R" calculated for the last three categories of the tool of weethol was less than the tabular and negative evidence of the existence of an inverse relationship between the direct categories of tool and thaw and stimulating student activity.

The first hypothesis, in which we assume that there is a positive correlation between the three direct categories of a tool, a tool, and the extent to which the teacher encourages and motivates students to perform physical activity. To prove this hypothesis, it is shown to us through Table 4, and this result we have reached is consistent with the findings of previous studies, Clear Al-Amin, Muhammad George, and Saibi Yusef, where they came out with the conclusion that (there is a strong positive correlation between some characteristics of the professor's personality and the motivation of achievement among pupils towards the class of physical education and sports. Social relations have a great impact on learning among adolescents in the study of physical education and sports and relying on forming groups helps a lot in Knowledge and raising the level of pupils) and the researchers attribute this result to the fact that the teachers were indirect in their teaching and it becomes a work The professor is easy and effective, and Sarhan asserts, "The teachers' work becomes easier and more productive if the students are driven to self-learning and thus more attainable (Sarhan, 2015). Hall and others add, "It is the tendency to feel and act as if the individual is an influential factor in life events and not a helpless person. And weak ". Indirect methods of teaching are effective in stimulating students to take part in the work (Hull et al., 1987).

Regarding the second hypothesis, in which we assume that there is a negative relationship between the last three direct categories of the tool of weethol (behavior directed to students, the behavior of reprimand and reprimand and forgiveness, the behavior of strengthening the teacher for himself) and the extent to which the teacher encourages and motivates students to perform physical activity and to prove this hypothesis, it is shown to us through the three boxes The last of Table 4 and this result is in line with the findings of previous studies. It is clear to the Secretary where he came out with a result (that there is a negative relationship between the trait of aggression of the professor and the motivation of the level of ambition of third-stage secondary education pupils and a correlational relationship toward Positive between the calm character of the professor's personality and the motivation of perseverance among the students in the third year of high school) and the researchers attribute this result in that the more direct teachers they are in their teaching, the greater the behavior of rebuking, reprimanding and asking for forgiveness for the professor and the behavior of the professor's reinforcement of himself on his students and that is because of the large number of behavior directed to students, as teaching strategies can To talk to students and create motivation for them to learn this subject (Abu Salma, 1995, p. 24) and the professor here is less intrusive. It is only directed, and the professor's speech is little, which contradicts the concept of "the student at the center of the educational process" (Marwan, 2016) (The National Curriculum Committee, March 2015). Consequently, direct methods in teaching are ineffective to stimulate students to participate in work and thus not achieving teaching with competencies. Like what has stipulated in the second generation curricula Algeria and the goals remain mere rhetorical statements and slogans that rise above reality and distract from its concerns (Boussouar, 2016). Finally, we recommend the use of indirect methods by professors in teaching, whether verbal or kinesthetic - giving a large space when teachers form emotional-social interactions 
during Teaching - Holding training sessions for professors in various teaching stages and emphasizing the importance of social studies.

\section{Conclusion}

Through the results of the hypothesis, we conclude that the relationship is correlative between the behavioral groups: the first three of the tool of weethol and the extent of pupils' activity, which is consistent with the study of Clear Al-Amin and Saibi's study that "the relationship between the social trait of the professor and the motivation of achievement behavior among students is positively high" (Wadah et al., 2014; Mokhtari, Bensaibi, 2018), where previous studies, and our study, recommend attention to the psychological and social aspect of the education stage for pupils to move away from complete control and roughness in the treatment of students and try to approach them in solving their problems, which is what Zamali shows that the use of teaching with competencies, i.e. indirect methods in teaching, strengthens Some psychological skills such as self-confidence (Zamali, 2013). As for the inverse relationship between the behavioral groups: the last three and the extent of student activity, we find that they are consistent with the study of Boghalia and Ahmad. There is a weak correlation between the competencies of the professor of physical education and sports and the dimensions of the scale of the following trend: social experience, health experience, stress reduction, and athletic excellence (Boughalia, 2020), meaning that the study sample was direct in its work and did not consider social relations in the teaching of This requires us to prepare curricula that satisfy the emotional-social relations and to work with them with the establishment of training courses for teachers and to emphasize in them the importance of the professor's personality and his social interactions with students according to our curriculum.

\section{Acknowledgements}

I would like to sincerely thank all those who participated in this study, especially the Directorate General of Scientific Research and Technological Development DGRDST (URL: http://www.dgrsdt.dz/v1/?fc=Accueih1) for all the assistance provided to us in carrying out this research, as well as all the researchers, professors, students, their parents, teachers, administrators and all the administrative and pedagogical staff of the schools involved in the study, I also thank the University of Abdel Hamid bin Badis and the Institute of Physical and Sports Education in Mostaganem, Algeria, as well as the administrative staff of the European Journal of Physical Education and Sport- international scientific journal, and Academic Publishing House Researcher.

\section{References}

Abu Shun, 2002 - Abu Shun A. (2002). The effect of training uphill slopes in developing some types of speed for soccer players. Iraq: Master Thesis.

Ăğırbaş et al., 2019 - A ̆ğrbaş, Ö. et al. (2019). Investigation of Physical Activity Levels of High School Students According to their Exercise Addiction. Atatürk University. Journal of Physical Education and Sport Sciences. 21(2), June.

Ahmad Al-Amin et al., 2014 - Ahmad Al-Amin et al. (2014). Characteristics of the professor of physical education and sports and their relationship to the achievement motives towards the physical education and sports class of students. Journal of the Mathematical System, 114.

Aida Abdullah Abu Saimeh, 1995 - Aida Abdullah Abu Saimeh (1995). Anxiety and Academic Achievement, Arab Center for Student Services.

Akram Zaki Khatibiyeh, 1992 - Akram Zaki Khatibiyeh (1992). Contemporary Curricula in Physical Education, 2nd Edition, Jordan: Dar Al Fikr.

AlSawi, Ali Zainab, 2011 - Al-Sawi N.M., Ali Zainab, M. (2011). The effectiveness of visual exercises on cognitive skills, visual abilities and the level of offensive skills in handball. The Third International Conference. Developing educational curricula in the light of recent trends and the need of the labor market. Egypt. Vol. 3.

Bensabeur et al., 2020 - Bensabeur, M., Mokrani, D., Harbach, B. (2020). The Physical Conditions in Educational Institutions and their Relationship with the Teaching Performance in High Schools. Acta Facultatis Educationis Physicae Universitatis Comenianae. 60(1): 75-83.

Cairney et al., 2010 - Cairney, J., Hay, J.A., Veldhuizen, S., Missiuna, C., Faught, B.E. (2010). Developmental coordination disorder, sex and activity deficit over time: a longitudinal 
analysis of participation trajectories in children with and without coordination difficulties. Developmental Medicine and Child Neurology. 52: 67-72.

Canbolat, 2018 - Canbolat, D. (2018). Investigation of Physical Activity Level and SelfEsteem in Teachers. Master Thesis, Selcuk University, Institute of Health Sciences, Coaching Education Department, Konya.

Cherng et al., 2007 - Cherng, R.J., Hsu, Y.W., Chen, Y.J., Chen, J.Y. (2007). Standing balance of children with developmental coordination disorder under altered sensory conditions. Human movement science. 26(6): 913-926.

Doraj, 2012 - Doraj, F. (2012). Evaluating the effect of motor selective programs over perceptual-motor ability educational achievement of slow learning. The School Psychology Journal periodical. 1(4): 55-59.

Dos Santos, Vieira, 2013 - Dos Santos, V.A.P., Vieira, J.L.l. (2013). Prevalence of developmental coordination disorder in children aged 7 to 10 years. Revista Brasileira de Cineantropometria e Desempenho Humano. 15(2): 233-242.

Boughalya, 2020 - Boughalya, F. (2020). The teaching competence of a professor of physical education and sports and its relationship to the formation of female attitudes towards the practice of educational sports physical activity in the middle education stage. Journal of Science and Technology for Physical and Sports Activities, 166-180.

Harbach et al., 2018 - Harbach, B., Djourdem, B., Snouci, F. (2018). The effectiveness of the teaching-by-play strategy in developing some physical and motor abilities among secondary school students. Journal of Sports El ibdaa Mesila. [Electronic resource]. URL: https://www.asjp. cerist.dz/en/PresentationRevue/316. 6(03):131-118.

Harbach et al., 2019 - Harbach et al. (2019). A Comparison Study for the use of Mixed Training (Training with Weight and Plyometric) In the Development of the Distinctive Strength Speed as the Players of the Handball. International Journal of Physical Education, Fitness and Sports (IJPEFS). [Electronic resource]. URL: https://ijpefs.com/index.php/ijpefs/article/view/247

Harrow, 1990 - Harrow, A. (1990). The Classification of Educational Objectives in the Psychomotor Domain. Translator: Kyamanesh, Ali R: Iran Publication.

Helder, 2015 - Helder, J.C. (2015). Influence of a physical education plan on psychomotor development profiles of preschool children. Journal of human sport \& exercise. 10(1): 126. DOI: 10.14198/jhse.2015.101.11

Hrabach et al., 2016 - Hrabach, B. et al. (2016). The Effectiveness Of Teaching Strategy With Games In The Development Of Some Physical Capacities Among Primary School Students (6-8 Years). European Journal of Physical Education and Sport Sciences. 1(2).

Hrabach et al., 2020 - Hrabach, B. et al. (2020). The Suggested Educational Units Using the Game-Oriented to Improve the Coordination Skills of PrimaryStudents. European Journal of Physical Education and Sport. 8(1). DOI: http://dx.doi.org/10.13187/ejpe.2020.1.3

Hull et al., 1987 - Hull, J., Vantrenren, R.R, Virnelli, S. (1987). Hardiness and health, a critiqué and alterndive approach. Journal of personality et social psychology. 53(1): 518-530.

Marawan, 2016 - Marawan, J. (2016). The degree of knowledge of a professor of physical education and mathematics of the structural model of learning. Science and Technology Journal of Physical and Athletic Activities, 60.

Lopes et al., 2017 - Lopes, V.P., Stodden, D.F., Rodrigues, L.P. (2017). Effectiveness of physical education to promote motor competence in primary school children. Physical Education and Sport Pedagogy. 22(6): 589-602. DOI: 10.1080/17408989.2017.1341474

Muhammad Zamali, 2013 - Muhammad Zamali (2013). Contributions of teaching by approaching competencies on the self-confidence skill of secondary school pupils. Journal of Science and Technology for Physical and Sports Activities, 75-97.

Muhammad. Ziyad Hamdan, 1999 - Muhammad. Ziyad Hamdan (1999). Learning preparation and teaching modern education series, Amman - Jordan: House of Modern Education.

Öner, 2016 - Öner, S. (2016). Determination of Physical Activity Levels of Academic Staff Working at Firat University. Frrat University, Physical Education and Sports Department, Master Thesis.

Othman, Afaf, 2013 - Othman, M., Afaf, O. (2013). Motor skills of children. Alexandria: Loyalty to the world of printing and publishing. 
Sadiq Khaled Al-Hayek, 2018 - Sadiq Khaled Al-Hayek (2018). Contemporary curricula and strategies in physical education teaching, Amman: The Jordanian National Library.

Sarhan, 2015 - Sarhan, S. (2015). Citing Qaddour bin Dahma Tariq, the motivation for learning and emotional intelligence and their relationship to academic achievement among elementary school students in Gaza. Amman: Al-Baroni Publishing House.

Suhail, Mahdi, 2007 - Suhail, Q., Mahdi, M. (2007). Principles of statistics and social measurement. Mansoura University: Faculty of Arts.

The National Curriculum Committee, 2015 - The National Curriculum Committee. Physical education and sports curriculum for intermediate education, Algeria, National Curriculum Committee, 2015.

Yassin, Bin Saibi Yusef Mukhtari, 2018 - Yassin, Bin Saibi Yusef Mukhtari (2018). The effect of social relations on learning among adolescents in the physical education and sports lesson in light of the competencies approach. Journal of Science and Technology of Physical and Sports Activities, 181-192. 